\title{
Editorial
}

\section{Hypoparathyroidism Should Always Be Checked in Papilledema}

The term papilledema is most often understood as optic disc edema occurring as a consequence of intracranial hypertension. It has been proposed to use this term in this meaning only, excluding thus disc swelling from vascular causes, optic nerve neuropathies, or other reasons. ${ }^{[1]}$

The clinical picture of papilledema can actually also occur in patients with hypocalcemia of any cause. In the pediatric population, DeGeorge syndrome is one of the possible causes. ${ }^{[2]}$ Such papilledema is almost always bilateral and usually causes minimal or no reduction in visual acuity, sometimes even no blind spot enlargement, at least not early. There have been several documented cases of later papillary atrophy, however. The blurring of vision can sometimes be the leading clinical sign even in the acute phase. ${ }^{[3]}$

Most commonly, it has been reported with primary or secondary hypoparathyroidism. It occurs only when hypocalcemia is severe, and it improves with its reversal. The underlying pathophysiological mechanisms are not completely understood, but it seems likely that in severe hypocalcemia intracranial pressure can increase, probably due to cerebrospinal fluid (CSF) hypersecretion, less likely to decreased CSF absorption. ${ }^{[4]}$ Actually, papilledema in hypocalcemia probably represents one part in the spectrum of idiopathic intracranial hypertension. Some alternative theories have been proposed, including alterations in local tissue permeability, as there are case reports which show that the CSF pressures were normal. However, elevated CSF pressure has been documented in most cases. ${ }^{[5]}$

Hypocalcemia is actually a rare cause of papilledema. However, it can be diagnosed very easily with serum calcium measurement, which should not be omitted. Even in the absence of other signs and symptoms of hypocalcemia, one should keep this possibility in mind. The authors of the instructive case report "Afebrile seizures as initial symptom of hypocalcemia secondary to hypoparathyroidism" have reminded us on this fact. ${ }^{[6]}$

The diagnosis of hypocalcemia is more easily suspected with seizures. Both generalized and focal seizures can occur in hypocalcemia as the sole presenting symptom. ${ }^{[6,7]}$ The hallmark of hypocalcemia should be actually muscular irritability with tetany. However, some patients experience rather less specific symptoms as fatigue or depression. Low CSF ionized calcium concentrations can have convulsive effects even in patients without any paresthesias, stiffness, myalgia, or cramps.

Peter Gradisnik

Department of Pediatrics, Maribor Clinical Centre, Maribor, Slovenia

Address for correspondence: MD. Peter Gradisnik, Department of Pediatrics, Maribor Clinical Centre, Maribor, Slovenia. E-mail: peter.gradisnik@ukc-mb.si

\section{REFERENCES}

1. Friedman DI. Papilledema and pseudotumor cerebri. Ophthalmol Clin North Am 2001;14:129-47, ix.

2. Shaw NJ. A practical approach to hypocalcaemia in children. Endocr Dev 2015;28:84-100

3. Maheshwari R, Rani RP, Prasad RN, Reddy KT, Reddy AP. Visual disturbances as a presenting feature of pseudohypoparathyroidism. Indian J Endocrinol Metab 2013;17 Suppl 1:S219-20.

4. Gregoric A, Bracic K, Marcun-Varda N. Familial hypomagnesemia - Hypercalciuria and pseudotumor cerebri. Wien Klin Wochenschr 2001;113 Suppl 3:59-61.

5. Goyal JL, Kang J, Gupta R, Anand A, Arora R, Jain P. Bilateral Papilledema in Hypocalcemia. Del J Ophthalmol 2012;23:12730.

6. Gkampeta A, Kouma E, Touliopoulou A, Aggelopoulos E, Vourti E. Afebrile seizures as initial symptom of hypocalcemia secondary to hypoparathyroidism. J Neurosci Rural Pract 2016;7 Suppl 1:S117-9.

7. Mrowka M, Knake S, Klinge H, Odin P, Rosenow $\mathrm{F}$ Hypocalcemic generalised seizures as a manifestation of iatrogenic hypoparathyroidism months to years after thyroid surgery. Epileptic Disord 2004;6:85-7

This is an open access article distributed under the terms of the Creative Commons Attribution-NonCommercial-ShareAlike 3.0 License, which allows others to remix, tweak, and build upon the work non-commercially, as long as the author is credited and the new creations are licensed under the identical terms.

\begin{tabular}{|l|l|}
\hline \multicolumn{2}{|c|}{ Access this article online } \\
\hline Quick Response Code: & $\begin{array}{l}\text { Website: } \\
\end{array}$ \\
\cline { 2 - 2 } & \\
\hline
\end{tabular}

How to cite this article: Gradisnik P. Hypoparathyroidism should always be checked in papilledema. J Neurosci Rural Pract 2017;8:329. 